\title{
Implementasi Strategi dalam Penanganan Pembiayaan Macet di BMT UGT Sidogiri Tanggulangin Kabupaten Sidoarjo
}

\author{
Mustika Nur Alam ${ }^{1 *}$, Renny Oktafia ${ }^{2)}$ \\ ${ }^{1,2}$ Fakultas Agama Islam, Universitas Muhammadiyah Sidoarjo \\ *Email korespondensi: alammustika655@gmail.com
}

\begin{abstract}
This study aims to determine the implementation of strategies in handling bad financing at BMT UGT Sidogiri Tanggulangin due to a decrease in the nominal amount deposited by members due to the economic crisis during the Covid-19 pandemic, to deal with these problems, BMT UGT Sidogiri has a good strategy. The research results show that the strategies that have been used by BMT UGT Sidogiri Tanggulangin to deal with non-performing financing are proven to be able to overcome the problems that occur and have a good impact on customer responsibilities and obligations. This study uses qualitative research methods in order to clearly address the problems that occur and the strategies implemented by BMT UGT Sidogiri.
\end{abstract}

\section{Keywords : Bad Financing, BMT UGT Sidogiri}

Saran sitasi: Alam, M. N., Oktafia, R. (2021). Implementasi Strategi dalam Penanganan Pembiayaan Macet di BMT UGT Sidogiri Tanggulangin Kabupaten Sidoarjo. Jurnal Ilmiah Ekonomi Islam, 7(02), 778-785. doi:http://dx.doi.org/10.29040/jiei.v7i2.2467

DOI: http://dx.doi.org/10.29040/jiei.v7i2.2467

\section{PENDAHULUAN}

Negara Indonesia merupakan salah satu penduduk islam terbesar di dunia. Indonesia menjadi salah satu negara yang memilki jumlah lembaga keuangan syariah terbanyak yaitu sekitar 5.000 institusi yang terdiri dai 34 Bank Syariah, 58 Asuransi Syariah, 163 Bank Kredit Rakyat Syariah, 7 Modal Vantura Syariah hingga 4500-5500 Koperasi Syariah atau Baitul Maal wat Tamwil. Pada tanggal 8 Oktober 2015 Mentri Koperasi Dan Usaha Kecil Dan Menengah Republik Indonesia Nomor: 16/Per/M.KUKM/IX/2015 menetapkan terkait dengan pelaksanaan kegiatan usaha simpan pinjam dan pembiayaan syariah oleh koperasi. Terkait memperluas kesempatan berusaha bagi masyarakat untuk melaksanakan kegiatan usaha simpan pinjam dan pembiayaan syariah oleh koperasi yang semakin berkembang, sesuai dengan dinamika dan perubahan tata letak ekonomi dan social masyarakat, maka keputusan Mentri Negara Koperasi Dan Usaha Kecil Dan Menengah Republik Indonesia Nomor: 35.2/PER/M.KUKM/X/2007 tentang pedoman standar operasional manajemen koperasi jasa keuangan syariah dan unit keuangan syariah koperasi sudah tidak sesuai, sehingga perlu dilakukan penyempurnaan (Koperasi, 2015).

Indonesia disebut sebagai salah satu negara yang memiliki perkembangan penerapan ekonomi syariah yang baik. Dalam sisi sector keuangan mikro syariah juga terus tumbuh melalui koperasi hingga lembaga pembiayaan mikro syariah, khususnya dalam BMT, yaitu lembaga keuangan mikro syariah yang murni lahir dengan ciri khas Indonesia, dan memiliki fungsi amil Baitul Maal dan fungsi pembiayaan Baitut Tamwi (Soemitra, Andri, 2019). Perkembangan dan praktik BMT sudah sangat meluas di Indonesia, yang ditandai dengan berdirinya 4.500 unit BMT di seluruh Indonesia. Koperasi simpan pinjam syariah bagi kehidupan masyarakat Indonesia sangat dibutuhkan, salah satunya untuk modal usaha agar masyarakat dapat membangun suatu usaha. Hal ini diperkuat dengan adanya Dasar Hukum Peraturan Pemerintah No. 9 tahun 1995 tentang pelaksanaan kegiatan usaha simpan pinjam koperasi syariah (Koperasi, 2015).

Koperasi simpan pinjam syariah salah satu alternative yang telah terpilih diantara berbagai jenis bentuk perusahaan. Data pada grafik diatas menjelaskan bahwa koperasi simpan pinjam syariah di 
Provinsi Jawa Timur mengalami penurunan tiap tahunnya. Pada tahun 2017 koperasi simpan pinjam syariah aktif sekitar 27.683, kemudian data tersebut menurun di tahun 2018 yaitu sekitar 24.024 koperasi yang masih aktif, dan ditahun 2019 kembali mengalami penurunan yaitu sekitar 21.757 koperasi simpan pinjam aktif di Provinsi Jawa Timur (Kesehatan, Kementrian 2019).

\section{Diagram 1. Koperasi Aktif Provinsi Jawa Timur 2017-2019}

Sumber : Badan Pusat Statistik Provinsi Jaawa

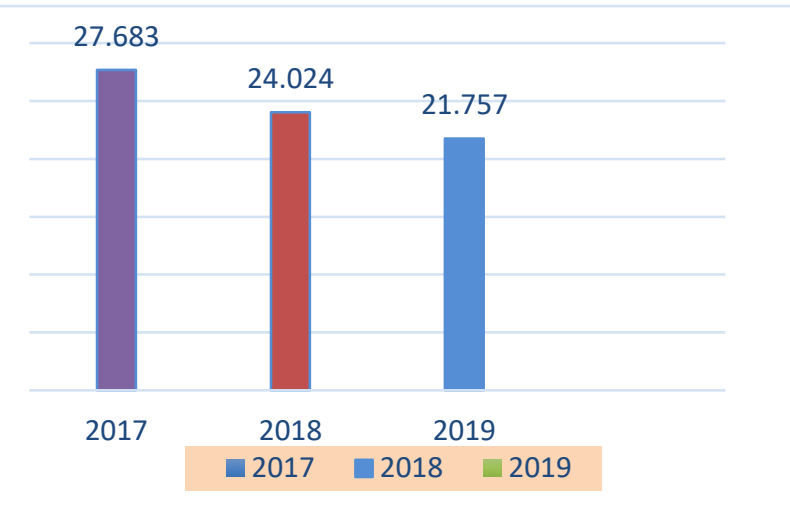

\section{Timur "Rekapitulasi Data Koperai Berdasarkan} Provinsi Per 30 Desember 2017-2019"

Perkembangan lembaga keuangan syariah di Indonesia melalui sisi implementasi diawali dengan beroperasinya perbankan syariah pertama yaitu Bank Muamalat Indonesia, namun pada saat ini jangkauan terhadap masyarakat yang memiliki usaha-usaha mikro kecil menengah masih sangat minim, sehingga dibutuhkan peran serta lembaga lainnya, yang ada sekarang ini yaitu Baitul Maal wat Tamwil (BMT) suatu lembaga yang sangat efektif untuk menyalurkan melalui lembaga keuangan bank tersebut. Baitul Maal wat Tamwil (BMT) merupakan suatu bagian dari bank syariah yang beroperasi seperti koperasi simpan pinjam syariah dengan pengecualian memiliki ukuran yang kecil dan tidak memiliki akses ke pasar uang (Sofhian, 2017).

Baitul Maal Wa Tamwil (BMT) merupakan suatu lembaga social yang dapat memberikan pembinaan bagi masyarakat yang ingin mengembangkan suatu usaha hingga masyarakat yang ingin membuka sebuah peluang bisnis, baik dalam pembinaan bisnis hingga pembinaan spiritual. Dalam adanya BMT akan memberikan bantuan untuk meningkatkan usaha masyarakat yang telah berjalan yaitu berupa tambahan modal untuk meningkatkan kapasitas usaha (Oktavia, 2014).
Koperasi simpan pinjam syariah BMT UGT Sidogiri Tanggulangin resmi dibuka pada akhir bulan Maret 2012, dimana kehadiran BMT UGT Sidogiri mendapatkan respon yang sangat baik dari masyarakat sekitar. BMT UGT Sidogiri memiliki manfaat tersendiri untuk masyarakat Indonesia atau sekitar, yaitu untuk menolong para pedagang agar tidak bergantung kepada rentenir dan terhindar dari riba. Terdapat kurang lebih sekitar 200 anggota peminjam di BMT UGT Sidogiri Tanggulangin, yang aktif melakukan pembayaran untuk melunasi setiap produk yang di pinjam, namun sebagian besar masyarakat indonesia kesulitan ekonomi karena adanya virus Covid-19 yang terjadi di indonesia, dan salah satu penyebab menurunnya perekonomian di Indonesia sehingga membuat anggota peminjam hanya dapat membayarkan setengah dari nominal yang akan disetorkaan.

Negara Indonesia saat ini tengah mengalami musibah yaitu adanya virus covid-19 yang membuat keuangan seluruh masyarakat Indonesia menurun, seperti halnya dengan permasalahan yang terjadi di koperasi simpan pinjam syariah BMT UGT Sidogiri Tanggulangin saat ini yaitu menurunnya jumlah nominal yang disetorkan oleh anggota, dan terdapat pula anggota yang hanya membayarkan keuntungan atau jasanya. Untuk menangani permasalahan tersebut pihak BMT UGT Sidogiri memiliki beberapa cara, yang pertama setiap anggota peminjam akan mendapatkan pesan terlebih dahulu sebelum tanggal pembayaran untuk mengingatkan, lalu pihak BMT UGT Sidogiri Tanggulangin akan melakukan sistem jemput bola bagi nasabah yang telat untuk melakukan transaksi pembayaran, namun bagi nasabah yang telat hingga jatuh tempo maka pihak BMT UGT Sidogiri Tanggulangin akan melakukan perpannjang waktu dan memberlakukan sistem denda yang telah disepakati sebelumnya oleh pihak BMT UGT Sidogiri Tanggulangin yaitu berupa membayar dana social. Berdasarkan pada latar belakang dan permasalahan yang terjadi di atas, maka peneliti dapat menentukan rumusan masalah yang akan diambil pada penelitian ini yaitu : 1) Bagaimana implementasi strategi dalam penanganan pembiayaan macet di BMT UGT Sidogiri Tanggulangin ? 2) Bagaimana dampak strategi dalam penanganan pembiayaan macet di BMT UGT Sidogiri Tanggulangin? 
a. Baitul Maal Wa Tamwil (BMT)

Baitul Maal Wa Tamwil (BMT) merupakan suatu lembaga keuangan mikro yang beroperasi menggunakan prinsip syariah. Baitul maal yaitu sebagai rumah harta yang memiliki tugas melakukan kegiatan usaha-usaha produktif dan investasi dalam meningkatkan kualitas ekonomi masyarakat, sedangkan Baitul Tamwil yaitu rumah pengembangan harta, yang bertugas sebagai menerima titipan zakat, infaq dan sedekah. Sedangkan secara garis besar BMT yaitu koperasi simpan pinjam syariah yang berfungsi untuk menghimpun dan menyalurkan dana kepada masyarakat bawah yang membutuhkan untuk membuka peluang bisnis (Soemitra, Andri, 2019).

Menurut Makhlul Ilmi, Baitul Maal Wa Tamwil yaitu suatu lembaga keuangan yang memiliki kegiatan utama untuk menghimpun dana masyarakat dalam bentuk simpanan atau tabungan hingga deposito, dan menyalurkan dana kepada masyarakat dalam bentuk pembiayaan yang telah di dasari dengan prinsip-prinsip syariah (Azizah \& Suprayogi, 2014). Dalam islam, koperasi syariah memiliki dasar hukum Al-Qur'an dan As-Sunnah. Al-Qur'an telah dijelaskan bahwa didalaam koperasi simpan pinjam syariah tidak menggunakan riba atau bunga. Adapun dalil baik dalam Al-Qur'an maupun Hadist sebagai berikut :

1) Surat Ar Rum : 39

Artinya : "Dan sesuatu riba (tambahan) yang kamu berikan agar harta manusia bertambah, maka tidak bertambah dalam pandangan Allah. Dan apa yang kamu berikan berupa zakat yang kamu maksudkan untuk memperoleh keridaan Allah, maka itulah orang-orang yang melipatgandakan (pahalanya)".

2) Surat Al-Baqarah : 275

Artinya: "Orang-orang yang memakan riba tidak dapat berdiri, melainkan seperti berdirinya orang yang kemasukan setan karena gila. Maka yang demikian itu karena mereka berkata bahwa jual beli sama dengan riba. Padahal, Allah telah menghalalkan jual beli dan mengharamkan riba. Barang siapa mendapat peringatan dari Tuhannya, lalu dia berhenti, maka apa yang telah diperolehnya dulu menjadi miliknya dan urusannya kepada Allah. Barang siapa mengulangi, maka mereka itu penghuni neraaka, mereka kekal di dalamnya”.

b. Pembiayaan Macet

Penyaluran dana oleh pihak kreditur terhadap pihak debitur agar dapat memenuhi kebutuhan, pihak debitur yang berkewajiban atau berjanji untuk melakukan pembayaran yang sesuai dengan jumlah dan jangka waktu yang telah ditentukan. Pembiayaan bermasalah merupakan suatu pembiayaan yang mengalami permasalahan terkait dengan pelunasan dikarenakan unsur ketidak sengajaan atau memang disengaja oleh pihak anggota bermasalah (Izza, 2018).

Menurut Aharsyah Ibrahim dan Arinal Rahmati, pembiayaan bermasalah secara umum merupakan suatu pembiayaan yang di sebabkan oleh prilaku atau tindakan anggota yang tidak melaksanakan kesepakatan yang telah disepakati dan juga tidak melakukan pelunasan sesuai dengan jangka waktu yang telah disepakati sebelumnya (Ibrahim \& Rahmati, 2017). Ada dua faktor penyebab terjadinya pembiayaan macet diantaranya :

1) Faktor Internal

Kurangnya tingkat analisa yang dijalankan oleh pihak internal sehingga menyebabkan pembiayaan bermasalah. Dan lemahnya monitoring dan pembinaan yang dilakukan oleh pihak internal (Akhir \& Khoerudin, 2015).

2) Faktor Eksternal

Terdapat unsur kesengajaan anggota, yaitu anggota sengaja tidak melakukan pembayaran dikarenakan anggota tidak memiliki kemauan dalam melakukan transaksi pembayaran. Dan unsur tidak kesengajaan, yaitu anggota memiliki kemauan untuk membayar sesuai dengan kesepakatan yang telah ditentukan, namun kemampuan anggota untuk membayar sangat terbatas sehingga tidak dapat memenuhi kewajibannya untuk membayar (Akhir \& Khoerudin, 2015).

Pembiayaan macet pada koperasi simpan pinjam syariah, dikategorikan berdasarkan dengan tingkat kelancaran anggota untuk membayar kepada lembaga keuangan. Menurut Andi Fariani dan Reni Supriyanti, pada 


\section{Jurnal Ilmiah Ekonomi Islam, 7(02), 2021, 781}

pembiayaan macet dapat digolongkan sebagai berikut (Fariana, 2017) :

1) Kolektibilitas Lancar

Dalam kredit dapat dinyatakan lancer ketika anggota pelaksana kredit tidak terlambat dalam melakukan pembayaran, baik dalam pengembalian pokok, jasa maupun bagi hasil yang telah disepakati bersama.

2) Kolektibilitas Perhatian Khusus

Pada pembiayaan, anggota yang mengalami keterlambatan pembayaran pokok, margin berserta angsuran selama 90hari, akan mendapatkan perhatian khusus dari BMT.

3) Kolektibilitas Kurang Lancar

Pada golongan pembiayaan kurang lancer yaitu apabila terdapat anggota yang berhutang atau tidak membayar angsuran pokok dan margin yang telah ditentukan hingga melewati batas waktu yang telah disepakati yaitu 90 hari hingga 180hari, maka termasuk kategori anggota kurang lancer.

4) Kolektibilitas Macet

Yaitu suatu kategori yang telah dinyatakan pembiayaan macet, dimana anggota tidak melakukan pembiayaan berupa pelunasan pembiayaan baik pinjaman pokok baupun pembiayaa bagi hasil hingga melampaui batas waktu 270 hari dari waktu yang telah di sepakati.

\section{METODE PENELITIAN}

Jenis Penelitian ini mengunakan metode peenelitian kualitatif. Metode kualitatif dipilih karena dianggap sesuai dengan permasalahan yang sedang diteliti yakni :permasalahan pembiayaan macet yang dialami BMT UGT Sidogiri, dimana menganalisis fenomena pada suatu tempat lalu memahami serta menganalisis permasalahan tersebut. Penelitian kualitatif bersifat tidak pasti dan masih terus berubah dan berkembang seiring dengan batas waktu (Sugiyono, 2013). Sedangkan jenis pendekatan yang digunakan yaitu pendekatan studi kasus yang mendlami secara detail bagaimana interaksi yang ada pada lingkungan social, individu, lembaga dan organisasi dengan permasalahan yang terjadi di tempat penelitian (Suharsimi, 2013).

Peneliti melakukan penelitian di BMT UGT Sidogiri yaitu Jalan Raya Ngaban Kecamatan Tanggulangin Kabupaten Sidoarjo untuk mendapatkan data tentang strategi penanganan pembiayaan macet. Penelitian dilakukan hanya satu perusahaan. Alasan memilih BMT Ugt Sidogiri dalam pembiayaan macet untuk strategi pembiayaan macet, karena ditempat yang peneliti ketahui BMT tersebut memiliki banyak nasabah dan lokasi dekat dengan pasar.

Sumber data dalam penelitian ini di dapat melalui sumber data primer dan sumber data sekunder.

a. Sumber Data Primer

Suatu data yang diperoleh peneliti melalui tangan pertama atau secara langsung baik melalui individu maupun perseorangan, seperti hasil wawancara atau mengisi hasil kuisioner (Dr. Harnovinsah, 2019).

\section{b. Sumber Data Sekunder}

Suatu data yang diperoleh peneliti melalui sumber yang telah tersedia atau data yang diberikan secara tidak langsung kepada peneliti, data sekunder juga dapat diperoleh melalui suatu referensi pustaka yang menjadi bahan utama dalam suatu penelitian dan dari haasil pemikiran lainnya (Sugiyono, 2013).

Adapun teknik pengumpulan data yang digunakan peneliti diantaranya yakni :

a. Wawancara

Teknik wawancara terstruktur dimana dalam hal ini peneliti telah mengetahui informasi apa yang hendak digali dari narasumber agar dapat mendapatkan data primer. Peneliti dapat menggunakan berbagai macam instrument seperti alat bantu recorder, kamera foto untuk mengambil suatu gambar yang dibutuhkan oleh peneliti, hingga instrument-instrumen lainnya (Sugiyono, 2013).

b. Observasi

Dalam penelitian ini, peneliti menggunakan teknik observasi non-partisipatory, dimana dalam teknik tersebut peneliti dapat melakukan pengamatan. Teknik pengumpulan data melalui observasi suatu pengumpulan data yang dilakukan peneliti agar lebih mudah mencari data melalui pengamatan, dan disertai dengan pencatatan terhadap prilaku objek yang dituju (Suharsimi, 2013).

c. Dokumentasi

Data penelitian ini diperoleh dari rekaman hasil wawancara, dengan kepala koperasi simpan pinjam BMT UGT Sidogiri. Dokumentasi perkumpulan dari seluruh data dari suatu peristiwa yang telah terjadi, dan tersimpan dalam 
bentuk teks atau naskah penelitian terdahulu (Dr. Harnovinsah, 2019).

Analisis yang dilakukan oleh peneliti selama dilapangan agar mendapatkan hasil yang maksimal, melalui dokumen-dokumen hingga wawancara, adapun tiga tahap dalam melakukan teknik analisis data pada penelitian ini yakni :

a. Reduksi data

Data yang diperoleh secara terperinci dan teliti, dengan menganalisis data yang telah terkumpul dan telah disusun secara sistematis yang berupa pokok-pokok permasalahan atau data yang dianggap penting (Dr. Harnovinsah, 2019).

b. Penyajian Data

Data yang dilakukan karena data yang terkumpul bervariasi, sehingga sulit menarik kesimpulan, untuk mengatasi hal ini dapat dilakukan dengan cara membuat suatu matriks sehingga data yang begitu banyak dapat dipilih dengan baik (Suharsimi, 2013).

c. Penarikan Kesimpulan.

Peneliti menarik kesimpulan berdasarkan dengan tema untuk menemukan makna dari data yang telah terkumpul (Sugiyono, 2013).

\section{HASIL DAN PEMBAHASAN}

\section{Implementasi Strategi dalam Penanganan} Pembiayaan Macet di BMT UGT Sidogiri Tanggulangin Kabupaten Sidoarjo

BMT UGT Sidogiri memiliki peran yang sangat penting dalam upaya meningkatkan strategi penanganan pembiayaan macet dalam hal produk pembiayaan. Salah satu produk pembiayaan yang sangat diminati oleh nasabah yaitu Modal Usaha Barokah (MUB) yang memiliki akad musyarakah atau murabahah jual beli. Pada saat ini banyak koperasi simpan pinjam syariah yang memberikan peluang nasabah agar dapat lebih mudah meminjam modal untuk membuka usaha, mengingat bahwa banyak diluar sana pemberian modal melalui rentenir yang akan berdampak buruk bagi nasabah yang melakukan transaksi salah satunya yaitu riba. Oleh karenanya BMT UGT Sidogiri Tanggulangin memberikan sistem alternative kepada nasabah agar dapat melakukan suatu transaksi ataupun pembiayaan yang didalamnya tidak menggunakan riba, dengan adanya koperasi simpan pinjam syariah akan memberikan dampak positif salah satunya bagi pihak BMT UGT Sidogiri
Tanggulangin dalam meningkatkan strategi penanganan pembiayaan macet.

BMT UGT Sidogiri merupakan suatu koperasi syariah yang telah berdiri pada tahun 2012 dan bernomor Badan Hukum: 199/PAD/M.KUKM.2/II/2015. BMT UGT Sidogiri mengalami perubahan ekonomi yang saat ini cenderung menurun sehingga menyebabkan pemasukan masyarakat juga menipis, dapat disimpulkan dalam diagram lingkaran sebagai berikut:

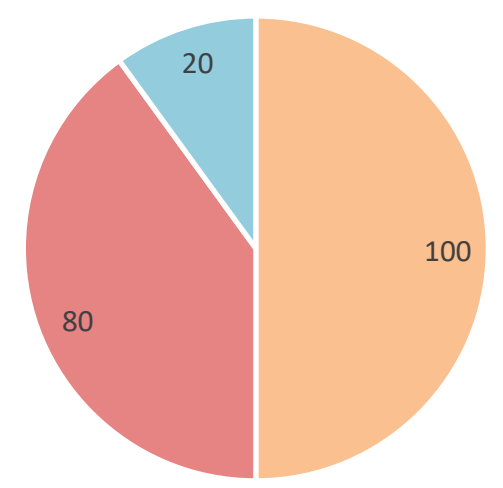

- Aktif - Kesulitan $\square$ Menunggak

\section{Diagram 2. Data Nasabah Peminjam Tahun 2020 \\ Sumber : Data Nasabah Peminjam 2020 Koperasi Simpan Pinjam Syariah BMT UGT Sidogiri \\ Tanggulangin.}

Pada gambar diagram diatas menjelaskan bahwa terdapat sekitar 200 nasabah peminjam yang diantaranya 100 orang aktif membayar dengan tepat waktu, 80 orang mengalami kesulitan membayar yang dikarenakan menurunnya pemasukan setiap bulan atau setiap tahunnya, dan 20 orang yang juga mengalami kesulitan hingga menunggak 2 - 3 bulan bahkan hingga sampai 1tahun lamanya. Di masa pandemi ini beberapa nasabah peminjam hanya dapat membayar pinjaman setengah dari nominal yang telah disepakati sebelumnya, misalnya dari kesepakatan awal nasbah yang akan membayar berjumlah $\mathrm{Rp}$. 2juta/bulan, di saat pandemi nasabah hanya dapat membayar Rp. 500.000 - Rp. 1juta saja perbulan. Keadaan social ekonomi pada BMT UGT Sidogiri juga mengalami penurunan yang dikarenakan nasabah peminjam juga sulit untuk membayar pinjamannya, namun BMT UGT Sidogiri Taggulangin terus berusaha agar setiap bulan atau tahunnya dapat mengalami peningkatan sekitar $1 \%-5 \%$. 
BMT UGT Sidogiri Tanggulangin mmemiliki strategi dalam menangani pembiayaan macet yang disebut sebagai warranty suatu jaminan asset atau barang-barang berharga milik peminjam, yang telah dijanjikan atau diberikan jika peminjam tidak dapat melunsi pinjaman yang telah dipinjam. Dalam koperasi simpan pinjam BMT juga memberikan surat nazar yang berisi tentang kewajiban kepada diri sendiri agar melakukan atau tidak melakukan perbuatan dengan maksud mengagungkan serta mendekatkan diri kepada Allah SWT. Dari hasil wawancara yang telah dilakukan peneliti terhadap salah satu narasumber yakni Kepala Cabang Pembantu BMT UGT Sidogiri Tanggulangin. Dalam pembiayaan yang sering dilakukan oleh BMT kepada nasabah, BMT sering menemukan nasabah yang kesulitan dalam melakukan pembayaran, jika dalam melakukan pembiayaan terjadi suatu hambatan atau pembiayaan macet maka pihak BMT akan melakukan beberapa strategi diantaranya yakni : a) Personal Selling, Dalam membentuk suatu kegiatan yang sering digunakan oleh BMT UGT Sidogiri Tanggulangin dalam penjualannya salah satunya yakni mendatangi nasabah potensial yang sering disebut sebagai sistem jemput bola. BMT UGT Sidogiri Tanggulangin menerapkan strategi jemput bola untuk menawarkan produk pembiayaan tanpa melalui prantara, hingga menjadikan suatu solusi bagi nasabah yang memiliki kesibukan dan tidak mempunyai waktu luang datang ke BMT UGT Sidogiri Tanggulangin untuk membayar pinjaman. Prosedur yang diberikan yakni pertama setiap nasabah akan mendapatkan pesan secara otomatis melalui ponsel sebelum waktu membayar contohnya nasabah memiliki waktu membayar pada tanggal 24 maka nasabah tersebut akan mendapatkan pesan 1minggu sebelum tanggal 24 , kemudian jika nasabah tersebut tidak dapat datang ke kantor biasanya nasabah memberikan informasi agar pihak BMT UGT Sidogiri Tangggulangin, dan salah satu karyawan yang telah ditugaskan akan mendatangi nasabah tersebut untuk mengambil pembiayaan dengan menggunakan strategi jemput bola. Layanan jemput bola yang dilakukan BMT UGT Sidogiri Tanggulangin yakni dari pukul $10.00-14.00$ WIB, hal tersebut dilakukan agar dapat memberikan kenyamanan dan meningkatkan pelayanan yang baik kepada semua nasabah BMT UGT Sidogiri Tanggulangin. b) Jaminan, Dalam suatu persyaratan yang diberikan oleh setiap koperasi simpan pinjam syariah salah satunya yaitu BMT UGT Sidogiri
Tanggulangin kepada calon nasabah, sebelum melakukan pinjaman nasabah harus menjaminkan suatu barang, harta atau benda yang akan diberikan kepada BMT UGT Sidogiri Tanggulangin. Dalam hal ini terdapat beberapa nasabah yang menjaminkan sebuah sepedah motor untuk dapat mengajukan suatu pembiayaan, jika nasabah tersebut tidak dapat melunasi pembiyaan maka pihak BMT UGT Sidogiri Tanggulangin akan memberikan suatu pilihan atau tawar menawar jika nasabah tersebut kesulitan dalam membayar, diantaranya yaikni pihak BMT UGT Sidogiri Tanggulangin akan memberikan tambahan waktu untuk nasabah agar dapat melunasi pinjaman tersebt, jika nasabah tidak dapat melunasi hingga jatuh tempo maka BMT UGT Sidogiri Tanggulangin akan meminta izin untuk menjual jaminan yang telah dijaminkan oleh nasabah pada awal melakukan suatu pinjaman. c) Jasa Badan Hukum atau Pengacara, Dalam suatu perusahaan seperti koperasi syariah atau BMT UGT Sidogiri Tanggulangin telah bekerja sama dengan badan hukum agar dapat memudahkan pihak perusahaan untuk menjalankan tugasnya, dalam hal ini terdapat salah satu nasabah BMT UGT Sidogiri Tanggulangin yang kesulitan untuk melunasi pembiayaan yang telah dipinjam, hingga pada akhirnya sampai jatuh tempo nasabah tersebut belum juga melunasi, telah dilakukan sistem jemput bola namun nasabah selal menghindar dan pada akhirnya pihak BMT UGT Sidogiri Tanggulangin menjual jaminan tersebut, namun hingga melebihi jatuh tempo pembiayaan tak kunjung lunas, untuk menghindari pembiayaan macet maka pihak BMT UGT Sidogiri Tanggulangin meminta bantuan kepada jasa badan hukum atau pengacara untuk memberikan penjelasan kepada nasabah yang telat membayar, agar nasabah tersebut segera melakukan pembayaran, jika hal tersebut tidak memberikan hasil yang maksimal, pihak BMT akan melaporkan hal tersebut kepada Badan Hukum atau kepada pihak yang berwajib.

\section{Dampak Strategi dalam Penanganan Pembiayaan Macet di BMT UGT Sidogiri Tanggulangin Kabupaten Sidoarjo}

Implementasi strategi yang telah dilakukan BMT UGT Sidogiri Tanggulangin terhadap pembiayaan macet berdampak baik bagi BMT salah satunya telah terbukti dengan adanya dampak strategi penanganan pembiayaan macet diantaranya yakni : a) Personal Selling, merupakan salah satu strategi yang diterapkan dalam setiap perusahaan. BMT UGT Sidogiri memiki 


\section{Jurnal Ilmiah Ekonomi Islam, 7(02), 2021, 784}

strategi yang diterapkan yakni jemput bola, karyawan ataupun kepala cabang dapat menawarkan produk pembiayaan tanpa melalui prantara, pengaruh personal salling terhadap penanganan pembiayaan macet di BMT UGT Sidogiri memiliki dampak yang positif dan signifikan, yang menunjukan bahwa kemampuan karyawan BMT UGT Sidogiri dalam melakukan penjualan pribadi atau menawarkan produk pembiayaan kepada nasabah hingga mampu membuat nasabah merasa puas dengan pemasaran yang telah diberikan oleh pihak BMT UGT Sidogiri. Namun terdapat suatu perbedaan dalam hal teori pemasaran secara langsung, dimana pelanggan dan calon pembeli mampu membangun suatu hubungan jangka panjang dengan karyawan dalam pembelian suatu produk pembiayaan, hal ini menunjukkan bahwa kurangnya informasi dalam menjangkau masyarakat sekitar BMT UGT Sidogiri. b) Jaminan, Dalam strategi penanganan pembiayaan macet di BMT UGT Sidogiri, jaminan merupakan suatu strategi yang diterapkan disetiap perusahaan salah satunya yakni koperasi simpan pinjam syariah BMT UGT Sidogiri. Jaminan memiliki dampak yang baik dan signifikan karena dengan adanya jaminan akan meringankan beban nasabah untuk melunasi pembiayaan dan memudahkan pihak BMT agar tidak ada terjadinya pembiayaan macet yang akan terjadi. Hasil wawancara yang telah di lakukan oleh peneliti, menurut Bapak Abdul selaku Kepala Kantor Cabang BMT UGT Sidogiri Tanggulangin menjelaskan bahwa terdapat beberapa nasabah yang memberikan jaminannya untuk melunasi pembiayaan dikarenakan nasabah telah kesulitan mengumpulkan dana untuk melunasi pembiayaan tersebut, cara kerja strategi jaminan yakni pihak BMT UGT Sidogiri sebelumnya akan melakukan diskusi bersama dengan nasabah, jika nasabah tersebut menyetujui jika barang berharga harus menjadi jaminan maka pihak BMT UGT Sidogiri akan mempermudah nasabah untuk melakukan pelunasan. . c) Jasa Badan Hukum atau Pengacara, Dengan adanya badan hukum atau pengacara dapat memberikan dampak yang baik bagi setiap koperasi simpan pinjam syariah salah satunya yakni BMT UGT Sidogiri. Strategi yang dilakukan yakni Badan Hukum atau Pengacara beserta pihak BMT UGT Sidogiri akan berkunjung kerumah nasabah yang memiliki permasalahan pembiayaan hingga jatuh tempo untuk berdiskusi, pengacara berserta pihak BMT UGT Sidogiri akan memberikan pilihan untuk nasabah antara lain yakni menjual jaminan atau pihak BMT UGT Sidogiri akan menyerahkan nasabah kepada pihak yang berwajib, hal ini salah satu dampak strategi yang dapat memudahkan pihak BMT UGT Sidogiri untuk menyelesaikan suatu masalah dalam pembiayaan macet, jika didalam suatu pembiayaan nasabah sulit untuk melakukan angsuran setiap bulan hingga menunggak sampai melebihi jatuh tempo maka termasuk dalam pembiayaan bermasalah, BMT UGT Sidogiri telah berusaha agar tidak ada lagi terjadinya pembiayaan macet, namun jika nasabah tidak dapat diajak bekerja sama dengan baik maka BMT UGT Sidogiri akan mendatangkan badan hukum atau pengacaara untuk melakukan suatu tindakan atau memberikan solusi agar dapat memudahkan nasabah dan pihak BMT UGT Sidogiri.

\section{KESIMPULAN}

Berdasarkan dari penelitin yang telah dilakukan serta hasil yang telah dipaparkan pada bab sebelumnya, peneliti telah menarik kesimpulan diantaranya yakni :

a. Dalam implementasinya BMT UGT Sidogiri melakukan penanganan pembiayaan macet dengan menggunakan beberapa strategi diantaranya yakni : 1) Personal Salling, BMT UGT Sidogiri Tanggulangin menerapkan strategi jemput bola untuk menawarkan produk pembiayaan tanpa melalui prantara, hingga menjadikan suatu solusi bagi nasabah yang memiliki kesibukan dan tidak mempunyai waktu luang datang ke BMT UGT Sidogiri Tanggulangin untuk membayar pinjaman. 2) jaminan, suatu persyaratan yang diberikan oleh BMT UGT Sidogiri untuk melakukan suatu pinjaman yang harus dijaminkan seperti barang, harta atau benda berharga yang akan diberikan kepada BMT UGT Sidogiri Tanggulangin. 3) Jasa Badan Hukum atau Pengacara, BMT UGT Sidogiri Tanggulangin telah bekerja sama dengan badan hukum agar dapat memudahkan pihak perusahaan untuk menjalankan tugasnya dan dapat menghindari adanya pembiayaan macet.

b. Strategi yang telah dilakukan oleh BMT UGT Sidogiri telah memberikan dampak yang baik bagi nasabah untuk bertanggung jawab dalam memenuhi suatu kewajibannya, dengan cara melakukan : 1) Personal Salling, memberikan dampak yang baik dan dapat menunjukan bahwa kemampuan karyawan BMT UGT Sidogiri dalam 
melakukan penjualan pribadi atau menawarkan produk pembiayaan kepada nasabah hingga mampu membuat nasabah merasa puas dengan pemasaran yang telah diberikan oleh pihak BMT UGT Sidogiri. 2) Jaminan, memberikan dampak yang signifikan dan dengan adanya jaminan akan meringankan beban nasabah untuk melunasi pembiayaan dan memudahkan pihak BMT agar tidak ada terjadinya pembiayaan macet yang akan terjadi. 3) Jasa Badan Hukum atau Pengacara, memberikan dampak yang baik bagi setiap koperasi simpan pinjam syariah karena dapat memudahkan pihak BMT UGT Sidogiri untuk menyelesaikan suatu masalah dalam pembiayaan macet.

\section{UCAPAN TERIMA KASIH}

Penulis mengucapkan terima kasih kepada lembaga pendidikan Universitas Muhammadiyah Sidoarjo, Kepada Bapak Hidayatullah selaku Rektor Universitas Muhammadiyah Sidoarjo, Kepada Ibu Istikomah selaku Dekan Fakultas Agama Islam, Kepada Ibu Fitri Nur Latifah selaku Kepala Program Studi Perbankan Syariah, Kepada Ibu Renny Oktafia selaku dosen pembimbing yang telah meluangkan waktu untuk memberikan masukan dalam penulisan artikel ini. Tidak lupa kamu ucapkan terimakasih kepada editor dan para reviewers yang telah membantu proses publish jurnal ilmiah di JIEI. Dan terimakasih kepada Koperasi Simpan Pinjam Syariah BMT UGT Sidogiri Tanggulangin yang telah memberikan izin serta membantu jalannya proses penelitian, serta teman-teman yang telah membantu memberikan solusi agar dapat menyelesaikan artikel jurnal ilmiah.

\section{REFERENSI}

Akhir, T., \& Khoerudin, A. (2015). Strategi mengatasi pembiayaan bermasalah di bmt atina banyubiru.

Azizah, R. A., \& Suprayogi, N. (2014). Analisis Keoptimalan Fungsi Baitul Maal pada Lembaga Keuangan Mikro islam. Jestt, 1(12), 841-852.

B, R. S., \& Fariana, A. (2017). Model penyelesaian sengketa ekonomi syariah yang efektif dikaitkan dengan kompetensi di peradilan agama dalam rangka pertumbuhan ekonomi nasional. Jurnal Jurisprudence, $\quad 7(1), \quad 68-79$. https://doi.org/10.23917/jurisprudence.v7i1.436 1
Dr. Harnovinsah, A. (2019). Modul 3 Metode Pengumpulan Data. Metodologi Penelitian, 3-5. Retrieved from http://www.mercubuana.ac.id

Ibrahim, A. dan, \& Rahmati, A. (2017). Analisis Solutif Penyelesaian Pembiayaan Bermasalah di Bank Syariah: Kajian Pada Produk Murabahah di Bank Muamalat Indonesia Banda Aceh. Iqtishadia - Jurnal Kajian Ekonomi Dan Bisnis Islam, 10(1), 71-96.

Izza, A. (2018). Strategi penanganan pembiayaan bermasalah produk multiguna tanpa agunan di bmt ugt sidogiri cabang pembantu tanggulangin sidoarjo.

Kesehatan, K. (2019). Laporan Data Koperasi Per 31 Desember 2019. $A \gamma \alpha \eta, 8(5), 55$.

Koperasi. (2015). Peraturan Menteri Koperasi Dan Usaha Kecil Dan Menengah Republik Indonesia Nomor 16/Per/M.KUKM/IX/2015 Tentang Pelaksanaan Kegiatan Usaha Simpan Pinjam Dan Pembiayaan Syariah Oleh Koperasi. Menteri Koperasi Dan Usaha Kecil Dan Menengah RI, 37.

Oktavia, R. (2014). Peranan Baitul Maal Wattamwil (Bmt) Terhadap Upaya Perbaikan Moral Masyarakat Di Kawasan Dolly Surabaya. AnNisbah: Jurnal Ekonomi Syariah, 1(1). https://doi.org/10.21274/an.2014.1.1.119-137

Soemitra, Andri, D. (2019). Bank\&Lembaga Keuangan Syariah (kedua; cahayapro, ed.). Retrieved from www.prenadamedia.com

Sofhian, S. (2017). Baitul Maal wat Tamwil (BMT) Berbasis Kearifan Lokal Gorontalo. Al-Ulum, 17(1), 166-182. https://doi.org/10.30603/au.v17i1.112

Sugiyono. (2013). Metode Penelitian Pendidikan Pendekatan Kuantitaif, Kualitatif, dan R\&DSugiyono. 2013. "Metode Penelitian Pendidikan Pendekatan Kuantitaif, Kualitatif, dan R\&D." Metode Penelitian Pendidikan Pendekatan Kuantitaif, Kualitatif, dan R\&D. https://doi.org/10.1. In Metode Penelitian Pendidikan Pendekatan Kuantitaif, Kualitatif, dan $R \& D$.

Suharsimi, A. (2013). Metodologi penelitian. Bumi Aksara. 